\title{
Processes of Domination in the Contemporary Workplace Managing Disputes in the Swedish Healthcare Sector
}

\author{
Nyberg, Daniel; De Cock, Christian
}

Document Version

Accepted author manuscript

Published in:

The Sociological Review

DOI:

$10.1177 / 0038026118825235$

Publication date:

2019

License

Unspecified

Citation for published version (APA):

Nyberg, D., \& De Cock, C. (2019). Processes of Domination in the Contemporary Workplace: Managing Disputes in the Swedish Healthcare Sector. The Sociological Review, 67(3), 689-705.

https://doi.org/10.1177/0038026118825235

Link to publication in CBS Research Portal

\section{General rights}

Copyright and moral rights for the publications made accessible in the public portal are retained by the authors and/or other copyright owners and it is a condition of accessing publications that users recognise and abide by the legal requirements associated with these rights.

Take down policy

If you believe that this document breaches copyright please contact us (research.lib@cbs.dk) providing details, and we will remove access to the work immediately and investigate your claim. 


\section{Processes of Domination in the Contemporary Workplace: Managing Disputes in the Swedish Healthcare Sector Daniel Nyberg and Christian De Cock}

Journal article (Accepted manuscript*)

\section{Please cite this article as:}

Nyberg, D., \& De Cock, C. (२०19). Processes of Domination in the Contemporary Workplace: Managing Disputes in the Swedish Healthcare Sector. The Sociological Review, 67(3), 689-705. https://doi.org/10.1177/0038026118825235

DOI: https://doi.org/10.1177/0038026118825235

Copyright (C) The Author(s) २०19. Reprinted by permission of SAGE Publications.

* This version of the article has been accepted for publication and undergone full peer review but has not been through the copyediting, typesetting, pagination and proofreading process, which may lead to differences between this version and the publisher's final version AKA Version of Record.

Uploaded to CBS Research Portal: May २०२० 


\title{
Processes of domination in the contemporary workplace:
}

\section{Managing disputes in the Swedish health care sector}

\author{
Daniel Nyberg (University of Newcastle) \\ Christian De Cock (Copenhagen Business School)
}

\begin{abstract}
The aim of this article is to explain how forms of consent-driven domination are produced over actors with critical capacity to question the processes of domination to which they are subjected. Drawing on observations of meetings during which actors evaluated employee sick leave, we show how domination is locally achieved in situated interactions by (a) constructing a specific situational reality, (b) transferring responsibilities in accordance with this reality, and (c) positioning the actors within the confirmed bounds of the situation. Domination is produced by exploiting a gap between the reified instituted reality and the lived realities of embodied actors. Doing so enables critique of the workplace to be absorbed and situational responsibility to be directed towards individual employees. Engaging with French sociologist Luc Boltanski's recent work, we refer to these processes as 'complex domination': the domination appears centre-less and well-intentioned actions by realistic actors result in asymmetrical outcomesthat is, the same people always lose.
\end{abstract}

\section{Key words:}

Boltanski, discourse, domination, health care, sickness absence 
For almost four decades, and in practically all advanced capitalist democracies, the welfare state has been under attack. Initially, critiques came from across the political spectrum, with the welfare state characterized as bloated, inefficient, and stifling freedom and choice (Dean, 2010). The political project of neoliberalism has addressed this by cutting welfare benefits, privatizing public sector functions, and conforming public institutions to the logic of the market (Munro, 2017). While the roll-out of the neo-liberal project has been state-specific, across advanced capitalist democracies there is a continuous emphasis on a limited reliance on state-provided services for basic welfare.

A key component of policies aimed at stemming growth in welfare demands and costs while increasing individual choice and freedom is ensuring that individuals play more 'active' roles in their own government and take 'responsibility' for their situations (Miller \& Rose, 2008). To create capacity for citizen responsibility, policies have given the unemployed, ill or homeless the 'freedom' to be enterprising and autonomous in their attempts to find employment, recover from illness or solve housing problems. Supporting states have promoted mechanisms to 'activate' citizens such as job coaching, healthcare choices and housing mobility (van Gestel, Nyberg and Vossen, 2015). Thus, reductions in entitlements have been accompanied by policy instruments - New Public Management - that require welfare subjects to take personal responsibility for their adverse circumstances and to find solutions by being flexible, creative and reflexive.

From these societal principles of flexibility and self-regulation derive new forms of domination within organizations. Direct and top-down approaches have been replaced with more indirect processes that mobilize ideological resources, producing consensus and consent in organizational life. Domination in organizations has become a process of naturalizing a particular social order and ensure the obedience of the employees. In an influential study, Burawoy (1979) detailed the importance of 'managing consent' to maintain and legitimate 
structures in organizations. Employees are viewed as active accomplices in their own exploitation by colluding with managers to achieve marginal gains through their own continuous subordination. Within this largely structural and deterministic explanation of domination, employees suffer from 'false consciousness' in that they consent to their own domination because they fail to understand and act to support their real interests. This echoes Bourdieu's (2001) position, and is similar to work in the Frankfurt School tradition, in that social actors are considered largely incapable of seeing through the veil of doxa and common sense.

This can be contrasted with a Foucauldian strand of domination discussing how neoliberalism fosters the development of self-regulation, with citizens disciplining both themselves and their peers through management techniques promoting responsibility, individuality, and freedom (Miller \& Rose, 2008). The autonomous agent is accountable for her or his own choices and has the capacity to contest the experienced domination (Martin \& Waring, 2018). This opens up an interesting tension on how domination happens and informs our guiding research question: How are new forms of consent-driven domination produced over actors with the capacity to question processes of domination?

We aim to address this conundrum by situating the dynamics of domination within a contextual political project with associated justifications. More specifically, we address this question by examining local disputes over illness-related absences in the Swedish healthcare sector. We conducted a qualitative in-depth study of status meetings which were called to discuss and evaluate an employee's sick leave situation and capacity to return to work. Observations of the meetings and subsequent interviews suggested that, although organizational arrangements and problems were always recognized as influencing the situation, the responsibility for the solution was continuously located with the employee. The instituted 
reality suggested that it was up to individual employees to reflect upon their career choices, better organize their work, and/or find other jobs.

By drawing insights from Boltanski's $(2008,2011,2013)$ recent writings on domination, we argue that a lack of resistance is not due to illusions or false consciousness; rather, employees form 'reasonable expectations' about what is achievable as they become aligned with a discursively constructed plane of reality consisting of rules and conventions: the instituted reality. Our analysis shows that domination at an organizational level becomes possible due to the establishment of a gap between the instituted reality and the lived realities of embodied individual actors in diverse everyday situations. This gap enables critiques of the current situation and workplace to be absorbed, thus making it possible to attribute legitimacy to domination. Since employees necessarily embody their own lived realities, this gap also enables critique of the workplace to be redirected toward individual employees.

\section{Boltanski and domination}

For Boltanski (and his co-authors) the broader structural terrain to which traditional theories of domination alert us needs to connect with a respectful and engaged understanding of the everyday perceptions of situated actors, and their multiple normative worlds and related justifications to enter disputes (Boltanski \& Thévenot, 2006; Boltanski \& Chiapello 2005). This is a horizontal view of 'critical capacity' where the researcher is placed on the level of the actors and is encouraged to examine organizational realities 'from within' (as opposed to taking the perspective of the objectifying scientist), i.e. from the perspective of embodied actors who engage in disputes (Stones, 2014). In trying to provide an answer to the question how domination is constructed and justified, Boltanski (2011, p. 23) thus exhorts us to to observe, naively as it were, what actors do, the way they interpret the intentions of others, the way they argue their case, and so on'. It is by looking closely at how actors actively engage in disputes 
over regulatory regimes - putting them to the test - that we can connect the structural perspectives of Bourdieu's 'critical sociology' and that of the Frankfurt School to the source of both domination and the resistance/acquiescence rooted in everyday organizational life.

In order to open up the analytical space for plural regimes of action and the discursive construction of domination, Boltanski $(2011,2013,2014)$ introduces a conceptual distinction between 'world' and 'reality'. To put it simply: the former is composed of 'everything that happens' whereas the latter encompasses 'everything that is constructed'. 'Reality' is based on a selection and an organization of certain possibilities offered by 'the world' at a given moment in time, apt to be grasped synthetically by local actors and researchers alike. In contrast, the 'world' cannot be conceivably totalized or analytically captured. Organizational actors thus face the ambiguity of a double attachment: they are situated in an organizational existence both 'as it is' and 'as it is constructed'. The significance of this distinction for our study is due to the fact that 'the world' of which organizational actors have direct experience is 'often out of kilter with ideological expectations, and constructions of social "reality", particularly in terms of those rules of what reality requires that are especially sensitive to the interests of the dominants' (Fowler, 2014, p. 83).

Institutions have the capacity to channel direct experiences of the world into a materially and symbolically mediated reality, which provides certainty and predictability to the organizational actors. For Boltanski (2011, p. 75), to the extent that '[a]n institution is a bodiless being to which is delegated the task of stating the whatness of what is', it is important to recognize that it is 'first of all in its semantic functions that the institution must be considered'. This semantic function 'consists in continuously confirming what is going on in the world and, therefore, in stabilizing the world' (Boltanski, Honneth and Celikates, 2014, p. 577). Institutions can determine the vocabulary mobilized by organizational actors when they 
attribute meaning to the world and they can thus set the parameters for specific grammars of interaction.

Institutions have developed visible formats and procedures to mediate between claims or disputes. Boltanski (2011) refers to these as 'reality tests' because testing organizational values against the reality of organizational processes enables actors to confirm the existing setup or hold it accountable for not living up to its own ideals. Reality tests thus enable critique that deploys argumentation and evidence to challenge certain representations of reality; through these tests, organizational and institutional practices, their outcomes and their relationships to normative structures become subject to scrutiny. Reality tests are 'drawn up according to predefined procedures and formats, to which their more specifically "local" implementation is bound to conform' (Boltanski, 2008, p. 46). Examples enacted in organizations include selection processes, dismissal procedures, formal decisions about different types of grievances, and in our context, status meetings.

When taken seriously, reality tests can have a disruptive effect, either by unmasking contradictions between various forms of normative expression, or by revealing dimensions of organizational life that might have been ignored. But in entering the tests the actors implicitly acknowledge (or are forced to acknowledge) the validity of the forms of organization that are guaranteed and reproduced by the test formats; in Boltanski's (2011, p. 107) words, they acknowledge 'the reality of reality'. Hence, those holding organizations to account, pointing to what they perceive as failures of the organization, always do so against the odds and actually make themselves vulnerable by drawing attention to 'offensive factors that have hitherto remained unacknowledged' (Boltanski, 2011, p. 107).

Boltanski's engagement with various theoretical traditions (Frankfurt School, Bourdieu, Foucault) and his own theoretical developments offers us a conceptual map with which to tackle our case study and sketch out some broader implications. First, Boltanski 
extends the 'critical sociology' of those working in the Frankfurt School tradition (e.g. Adorno, Marcuse, and more recently Honneth) and those inspired by the work of his one-time mentor Bourdieu, by elaborating how the widespread presence of critical processes within contemporary organizations - which have the ostensible aim of excluding the possibility of domination - enable the attribution of an unprecedented degree of legitimacy to domination. Critique thus has the potential to contribute to, rather than counter, the reproduction of social domination (Stones, 2014).

Second, Boltanski's emphasis on the diversity of regimes of action (Boltanski \& Thévenot, 2006) and on the variety of 'tests' undertaken in order to preserve or subvert them, echoes the work of Foucauldian scholars highlighting the plurality of regimes of power and the multiplicity of épistèmes (Foucault, 1970) generated in order to sustain or undermine them. Boltanski recognizes the disseminated nature of power stressed by Foucault, resisting the temptation to reduce 'human interactionality to a monolithically constituted process steered by an overarching logic permeating the entirety of relationally constructed realities' (Susen, 2014, p. 660). For Boltanski, domination is rather centre-less and devoid of any clear strategic intent as it depends on power structures which are amorphous and lacking an organizational epicentre. The somewhat contradictory notion of 'intentionality without strategic intent' thus refers not to the intentionality of any particular actor but to the empirical observation that it are 'always the same people... who, confronted with all tests... prove mediocre, unworthy people' (Boltanski, 2011, p. 38 - emphasis in original). The naive observation that the same people always seem to face the same inevitable outcomes indicate there is some, albeit amorphous, intentionality present in the overall set-up. Indeed, it would make little sense to talk about 'domination' if this were not the case.

The outline of Boltanski's position on domination supports a response to our broad research question - How are new forms of consent-driven domination produced over actors 
with the capacity to question processes of domination? - in two central aspects. First, the investigated status-meetings have a specific format and were introduced by the government (legislation) and organizations (policies) as a means of deepening the accountability of practices according to a coherent and progressive conception of social order. On the one hand they create a stable and authoritative environment, but on the other they also allow the actors involved to enter into disputes over the new regulatory regimes. Attention to the local interaction where a variety of organizational actors bring multiple regimes of action to the test can this provide us with insights into processes of domination. Second, in engaging in these tests the actors to a large extent perform the social in trying to agree upon a particular reality. Our study focuses on what holds this reality together, "what argumentative structures and what systems of proof are available to grant credibility to one particular picture of reality rather than some other" (Boltanski, 2014, p. 36). Plural actors' perspectives become 'observable' through how they produce criticism and justifications which, in order to be judged acceptable, have to be able to justify the relations that they weave with other propositions already held to be 'true', with the latter to be found in wider societal discourses.

\section{Methods and context}

Sweden is known as a social democratic welfare regime with generous sickness insurance. However, following an economic crisis in the early 1990s, there was a 'system shift' with clear inspiration of neoliberal ideas of marketization, decentralization and privatization of social services aimed at shrinking government (Larsson, Letell and Thörn, 2012). The advancement of neoliberalism influenced public policy towards mechanisms of responsibilization-people governed through freedom-where 'users' of welfare services control their needs, are empowered to make rational choices, and take responsibility for past (bad) choices. 
This change in the principles governing rights and obligations within the Swedish welfare model became evident in legislation and public policy documents addressing bloated and inefficient welfare regimes around, for example, social insurance. Sweden had one of the highest sickness absence rates in Europe between 1999 and 2003, and at 5.2\% in 2003, it was about twice as high as the European average (Lusinyan \& Bonato, 2007). During that year inhabitants between 16 and 64 years of age were sick on average 41.8 days per year (Svärdman, 2006). In the early 2000s, the issue garnered public attention and it became one of the most controversial topics in the Swedish media, with the formulation of the problem as Sweden having a 'sick leave culture' (Björnberg, 2012, p. 76).

Status meetings were introduced in 2003 to strengthen the National State Insurance Agency's (NSIA) capacity to deal with sickness absences and public insurance costs. If the employee refuses to participate, NSIA can stop paying out sickness benefits. The objective of the status meeting is 'in part to clarify what the employee can and cannot do based on his or her illness, and in part to decide what measures are required for the employee to be able to return to work' (NSIA, 2016). Meeting times are set based on employees' needs and important rehabilitation milestones. A status meeting is conducted with the employee and at least one other participant who can influence the rehabilitation (e.g., doctor or employer), depending on the situation. The meeting provides an opportunity for the actors to convey things that otherwise can be hard to clarify, such as the employee's motivation to return to the workplace and potential workplace accommodations. To further address the sickness absence problem in Sweden, additional policies were introduced on 1 July 2008 that restricted the previous unlimited leave period to one year and enforced stricter timeframes for assessing and managing long term sickness absences. It was made explicit that during this timeframe it is the employer's responsibility to investigate, coordinate, and pay for possible methods of rehabilitation at or in relation to the workplace. 


\section{Data collection}

Our empirical investigation is built around observations of 10 status meetings equally distributed between two Swedish hospitals during 2008-2010. We selected cases that were long-term (more than six weeks) and disputed, with at least two of the involved actors suggesting that the situation was due to organizational factors. All ten cases involved female employees. This is not that surprising as women form a significant majority of those employed in healthcare as well as being over-represented when it comes to long-term sick leave in Sweden (65\%) (NSIA, 2015). Reasons given for the long-term illnesses included work hazards and arrangements (e.g., wet floors and heavy lifting), work structures (e.g., workload and pace), and work processes (e.g., lack of training). Cases included psychological illnesses (e.g., depression) as well as physical illnesses (e.g., back problems) (see Table 1). In all of the chosen cases, a status meeting was deemed necessary to resolve the dispute or disagreement. This meant that the actors' positions required justification to the other actors involved. This is in contrast to short-term illnesses (e.g., a cold or food poisoning) or long-term illnesses (e.g., a broken leg or cancer), where the different actors immediately agree on a recovery plan.

Material for each case was assembled through observations (10 in total) and interviews (34 in total) which took place between late 2008 and early 2010 (see Table 1). NSIA coordinators facilitated access to the status meetings by asking the participants when they scheduled the meetings if they consented to a researcher being present. We subsequently observed the status meetings attended by relevant actors (e.g., employee, line manager, human resources manager, medical doctor, NSIA coordinator) and recorded and transcribed them verbatim (except the status meeting regarding Maria's case, during which we took extensive notes). The status meetings lasted between 14 and 55 minutes (37 minutes, on average).

We interviewed the actors who attended the status meetings immediately after the meetings or within a couple of weeks. The interviews made it possible to further understand 
and contextualize how the local actors made sense of the situations. We performed semistructured interviews to gather information on personal background, the sickness absence, the roles of the different actors, and the actions undertaken by all actors involved. The interviews clarified the actors' positions in the disputed situation, events during the meeting, and their broader understandings of the sickness absence process. The 34 interviews lasted 32 minutes on average, and were recorded and transcribed verbatim. All participants are given pseudonyms.

$$
==\boldsymbol{=}=\boldsymbol{=}=\boldsymbol{=}=\boldsymbol{=}=\mathrm{INSERT} \mathrm{TABLE} 1 \mathrm{AROUND} \text { HERE }==\boldsymbol{=}=\boldsymbol{=}=\mathbf{=}=
$$

\section{Data analysis}

The first step in our analysis was to identify the uncertainty or dispute underlying the requirement for a status-meeting. We paid attention to how each situation was constructed locally, rather than limiting ourselves to the initial medical rationale. The different actors in each case put forward a range of theories and explanations as to why the employee was reported as 'long term ill'. In all these cases workplace arrangements were criticized and it would be therefore reasonable to expect that at least some of the outcomes would require the organization to assume responsibility. However, in all 10 cases, the disputes were settled with the employees responsible for finding solutions. This initial finding guided the subsequent step in our analysis.

In the second step of the analysis, we zoomed in on the meetings as negotiation sites where disputes or uncertainties are resolved (Wodak, 2013). The meetings functioned as observable sites for how actors 'grant credibility to one particular picture of reality rather than some other' (Boltanski, 2014, p. 36). The analysis established three emerging discursive movements comprising the domination process in the 10 cases: (a) the construction of realities, (b) transferring responsibility for the situation, and (c) positioning the actors within the confirmed bounds of the situation. While there are obviously specific relations within each of 
the 10 cases, we focused on the commonalities in order to explain domination in contemporary workplaces. Ours is necessarily a particular interpretation, our own construction of the social reality from the indeterminate 'world' of all what went on in the status meetings as we attempt to show the actors' reflexive competences in 'testing' the regime of actions in the findings section below.

\section{Findings}

NSIA coordinators called the status meetings to address ambiguities or uncertainties surrounding long-term absences due to illness. Three central actors were present in all meetings: the employee, an employer representative, and an NSIA coordinator. Despite the underlying disputed nature of the problem and uncertainty over what should be done, the actors attempted to reach a consensus in both understanding the situation and next steps (as required by the format of this reality test). In constructing the situation, the actors recognized three interlinked aspects: societal policy formats, organizational factors, and the capacity of the ill employee. The meetings were attempts to reconcile these aspects in establishing 'what is', which then justified 'what should be done'.

\section{Constructing realities}

The new public policy, with its rules and requirements, was scrutinized in the meetings. For example, Sofia criticised the policy for being 'unscrupulous'. In another meeting, the supervisor expressed the view that the policy application had 'a strange reasoning' (case Marie). In response to criticism or challenges, it was mainly the NSIA coordinators who explained the new policies. In doing this, they rarely defended the policy; they just stated that things simply were what they were and that the actors had to be realistic about what they could achieve. The justifications were tautological in that they were assertive without further 
reasoning: 'we have these rules, so they apply' (Coordinator, case Sofia). A certain reality was instituted through these interactions, and while the actors did not necessarily agree with the policy, there was no possibility to challenge the fundamental reality of its existence.

Criticism of organizational factors influencing the situation was explicit when, for example, an employee asserted, 'I don't want to go back to the work that made me sick' (case Helena). The negative influence of work on the employees' health was not contested by the supervisors, who confirmed the health implications of the work, including workloads (e.g., 'I know that we have been at a very critical [workload] level and that we probably have rolled off the cliff'; case Elisabet); work departments (e.g., 'the emergency ward is super-tough'; case Marie); and, work roles (e.g., 'medical orderly is unfortunately the heaviest occupation we have'; case Kerstin). The problematic nature of the workplaces were confirmed, with one supervisor suggesting it was a place 'very few of us are able to work at until we retire' (case Kerstin). The meetings appeared to reproduce an a priori generally shared understanding.

In contrast, the employee's individual experience and situation required an active construction in the meeting in order to be understood and shared, leading to a socially negotiated 'truth' about the employee and her capacity. For example, in discussing the workload, the coordinator during the meeting in case Elisabet affirmed how the employee viewed the world and inferred that her depression made her incapable of properly understanding the situation:

Coordinator: Well, of course since you haven't felt that good, you experience the situation differently. That is how it is.

Supervisor: Exactly.

Elisabet: $\quad$ Yes.

Coordinator: And it is not always easy when you sort of feel how it just grows in your head and you cannot really understand the situation. 
Here, the coordinator and the supervisor constructed the employee's feelings, priorities, and experience of the situation.

By constructing a certain 'truth' about each employee and her experiences, actors also created implications for how to resolve the disputed situations. They did so by nominating personal attributes of employees. For example, Maria was told that: 'you are artistic, perhaps you should work with flowers'. By paying the employee a compliment, for example by suggesting that she is 'a lady with drive' (case Helena), the other actors moved the discussion towards the employee and her illness and away from the workload problems raised by actors during the meeting.

In constructing the reality of the sickness absence situation, the actors involved in the meeting instituted the public policy, confirmed an organizational reality, and constructed the employee's experience and situation. While all areas could be critiqued, it was only the employee's experiences that were ultimately considered malleable and therefore modifiable. The ambiguity and complexity of each individual's experience required an active construction to be shared among actors. The differences in plasticity of these aspects of reality enabled the process of domination where even sympathy and compliments act on, rather than for, the individual employee.

\section{Transferring responsibility}

Status meetings functioned as 'reality tests' in assessing the situated application of public policy, work arrangements and the insured's capacity to return to work. Depending on how a situation was defined, different contingencies assigned responsibility to different actors. Thus, the meetings involved struggles between actors as they negotiated who would assume responsibility for finding a solution, and the local specificity of what was being tested. During 
the meetings, subtle and not-so-subtle shifts could be observed. For example, during the meeting Sofia attempted to place the responsibility with the NSIA and the employer:

Sofia: $\quad$ And it is the employer and NSIA who has the responsibility for my rehabilitation.

Coordinator: Yes, it is the employer who has the main responsibility.

Sofia: $\quad$ Yes.

Coordinator: Then NSIA has the coordinating responsibility...

In the discussions, the coordinators, at times, shifted the responsibility to the employer and different solutions to the work situations were discussed. For example, Kerstin's supervisor suggested in the meeting that Kerstin could try a different work role: 'we can try something [a work role] that is called patient-placement coordinator'. While this particular offer was later withdrawn, in other cases the discussions in the meeting resulted in minor changes to the workplace, including the special fitting out of offices.

Responsibility was also transferred to the employee in the meetings. In the case of Inger, the supervisor spelled this out: 'This is where your responsibility comes in and where you take responsibility for your illness'. In the meeting of case Elisabet, this led to a discussion of possible solutions:

Coordinator: Well yes, do you have any thoughts yourself [directed towards the employee] on how we can or could find solutions for this?

Elisabet: $\quad$ No.

Coordinator: Not at all?

Elisabet: $\quad$ No, well, I haven't thought that much about it. Not beyond what I would like to, what we discussed before, that one perhaps discusses employing more staff, but I don't really know. It's hard.

Coordinator: Yeah, I understand. 
Elisabet: Really.

Coordinator: Do you think it would be easier to get your capacity to work back if you worked somewhere else, as a secretary here within the organization?

Elisabet: $\quad$ I really don't know...

The NSIA coordinator first directed the responsibility towards the employee. In response, Elisabet suggested changes to the workplace, but then the coordinator transferred the responsibility back to Elisabet by suggesting that she test her work capacity elsewhere. The premise is that employees should take responsibility for past (bad) choices.

The status meetings were called to test the situations, with the actors evaluating them and discussing the responsibilities of the different actors. In doing this, the coordinators and supervisors openly discussed the new policy and potential solutions. However, while they recognized this responsibility, they only represented the organization (NSIA or hospital) that had the responsibility. In contrast, employees could not separate their own actions from their responsibility. In the following section, we show how this crucial distinction enables the process of consent-driven domination.

\section{Positioning actors}

The meetings constructed a local social reality comprised of policy rules, the enacted formats of the meetings, and knowledge of the workplace as well as the employees. The employees showed critical capacity to question this reality. For example, Sofia questioned the policy application by asking the coordinator: 'do you think I'm stupid or it doesn't matter what I think?'. This criticism was met with the coordinator distancing herself from the instituted reality and explaining that 'it doesn't matter what I think either'. This example is indicative for how the supervisors and coordinators generally accepted the critiques put forward by the employees and agreed that the instituted policy and work environment had negative 
consequences for the employees' situations. When an employee critiqued the workplace, there was no disagreement over the fact that the workplace was 'super-tough' or 'heavy'. On the contrary, the supervisors confirmed this construction of the workplace. Although the critique was seen as legitimate, it had no bearing on outcomes. The confirmation or even recognition of responsibility did not change the organizational situation; the critique was simply absorbed. Actors accomplished this by (a) distancing themselves from the instituted reality, or (b) positioning themselves on the side of the employee.

First, by separating themselves from the demands of the situation, the supervisors and the coordinators in the meetings either referred to the economic situation, or their role in a political situation or hierarchy. For example, when Marianne suggested that the organization needed to hire more personnel, her supervisor referred to the undisputable reality of "what we can finance'. Similarly, when Elisabet proffered the same solution to deal with the workload, her supervisor referred to the organizational hierarchy that tied his hands: 'I have of course signalled this [being understaffed] to my line manager but she is not in a position either to decide on new employments'.

Likewise, coordinators sometimes positioned themselves as separate from the NSIA and the instituted realities of policy rules and evaluations. This was evident in how coordinators referred to institutional budgets or the monetary 'truth' of the new sickness absence policy: 'the belt is tightened when it comes to sickness benefits' (coordinator, case Ingrid), or when they explained how the NSIA evaluated the situation (even though they themselves were conducting the local evaluations in these cases). The coordinators thus separated themselves as actors from the institution they represented.

Second, the supervisors and coordinators connected their positions with those of the ill employees. For example, by showing sympathy, Marianne's supervisor tried to put herself in Marianne's situation: 'I can only imagine your situation: Do I have angina or something else? 
What may happen to me tomorrow, can I get a myocardial infarction? I can only try to envisage the worries'. In another case, an NSIA coordinator was empathetic in applying the policy to the situation: 'unfortunately, the situation is such that we have to do this [asses the ability to perform the current work] within 90 days of the sick leave' (case Ingrid). The situation is articulated as beyond their influence and the outcomes seen as inevitable; coordinators and supervisors were able to 'side' with employees against the new regulations while deflecting pertinent criticism. This was not malicious and did not appear intentional; rather, coordinators and supervisors seemed to be expressing frustration that they could not do more or that employees were trapped between organizational and societal realities. The critique of the workplace or new policy gains no grip, since the instituted reality simply confirms a particular situation.

In contrast, the employees did not have the same opportunity to distance themselves from critique. For example, during the status meeting, Marie confirmed that she was 'still ill'. In all the cases, employees used their illnesses to justify their sickness benefits; although the employees received benefits because they had certified medical conditions, the construction of their illnesses during status meetings also directed evaluations toward their individual experiences. Thus, employees could not distance themselves from their illnesses.

Similarly, the employees confirmed the constructions of their experiences by the other actors. In confirming that they 'take on others' tasks' (case Inger), 'that it [the illness] is hard' (case Elisabet), and that they 'lack strength' (case Kerstin), the employees assumed personal responsibility for their situations. While recognizing that the work made them ill, the employees embodied the critiques and enacted the responsibility. The critique put forward in the disputed situation gained traction as employees embodied their justifications for being ill and alternative solutions were dismissed. 


\section{Domination: Asymmetrically embodying and absorbing critique}

Our findings illustrate how all actors in the status meetings engaged in constructing the employees' experiences and identities. Supervisors and coordinators often used sympathetic terms to describe the employees' situation; in response, employees confirmed that they were not feeling well or were working too hard. The findings also showed how the supervisors and coordinators accepted critiques of both the new policy and the working conditions. However, the actors situated themselves differently towards these constructions: the employees embodied the constructions of their experiences, while supervisors and coordinators distanced themselves from the instituted reality and, in doing so, absorbed critiques of their organizations.

The findings show how each employee embodied and represented the existential reality of her life and how the status meeting's format and evaluative purpose promoted 'confessions' by the employee in disclosing symptoms (cf. Foucault, 2014). She could not dispute the organizational reality, because it was the reason she was ill in the first place; moreover, aligning her arguments about a tougher policy reality at the societal level with those of 'the experts' left no position from which to challenge the instituted truth. Stating the embodied truth about herself to others simultaneously objectified the employee and subjected her to (self-) examination. Through detailed descriptions of illnesses and consequences, the employee became the object of the truth, thus making her governable through this revealed knowledge.

Support for the employee created a gap between the actors representing the organizational (supervisor) and societal (coordinators) realities and the disembodied institution of rules and definitions. The supervisors and coordinators functioned as the representatives of bodiless entities. Since as spokespeople for the institution they can also distinguish themselves from the institution, their positioning allows for the absorption of responsibility and critique. Rather than rejecting critiques of the test format and their situations, the actors often affirmed them. The justified critique is then absorbed as 'letting off steam' and the social reality is 
confirmed. We thus witnessed a social asymmetry grown out of unequal relations to institutional procedures and rules. The employees in our case studies were required to follow these to the letter; while supervisors and NSIA coordinators did not stay in the official register all the time but displayed a certain fluid interpretation, most notably by playing on the ambiguity between their professional (representing the organization/ institution) and private (fellow worker/human being) roles.

Domination at work is thus, at least in principle, criticisable. In fact, under the normative parameters of the 'new spirit of capitalism' (Boltanski \& Chiapello, 2005), organizational actors (e.g., employer representatives, doctors, union representatives, NSIA coordinators, employees) are not only allowed, but also expected to mobilize their critical capacities. Yet, meeting outcomes were invariably the same, with the employee constructed as falling short of acceptable societal performance. Somewhat perversely, it was precisely the dynamic of justification and critique that appeared to give the decisions and outcomes legitimacy. The effects of domination can therefore be characterized by their capacity to deprive critique of any effect on organizational/societal reality and by asymmetrical and prejudicial outcomes for individual employees. The increase in individual freedom proclaimed by the neoliberal project paradoxically represents an intensification of domination in that employees are expected to take responsibility and actively address consequences of situations over which they have no control.

\section{Discussion}

In this research, we investigated how consent-driven domination is produced over actors who dispute the construction of local reality. We have shown how domination is enacted by legitimizing critiques of the instituted reality while individualizing responsibility for the disputed situation. In our context, critiques of inaccessible authorities and organizational 
bureaucracies were deflected back onto the employees. Although affected actors may consider a representation of the reality in which they are immersed to be unfair, they recognize their limited capacity to act, are realistic in their demands, and commonly accept 'the reality of reality'.

This consent-driven domination is not based on a collusion of interests, but on a particular construction of reality. The lack of resistance does not suggest that active consent is manufactured through abstract processes of domination (Burawoy, 1979). On the contrary, domination is local and results in the corporeal experience of not being able to have one's critique influence reality. Systemic domination is locally enacted, often by actors who do not necessarily support the actual consequences. The dominant actors (e.g., the supervisors and coordinators in our case) are also caught up in various impersonal and disembedded networks that limit their autonomy. Even so, the findings show how the supervisors and coordinators translated the governing rationality of activation in making it meaningful to the local setting. This supports research investigating management techniques promoting responsibility and selfgovernment within the setting of healthcare organizations in other countries (see e.g. van Gestel et al, 2015; Waring \& Latif, 2017). These 'intermediaries' between national policies and individual situations employed their professional legitimacy to normalize the 'reality' of selfgoverning subjects (Waring \& Latif, 2017).

These insights extend Boltanski's theorization of domination in capitalist democracies by detailing specific domination processes that produce asymmetrical effects. Boltanski has paid little attention in his own body of work to the composition of social settings as they are constructed and experienced by human actors. By attending to the local construction of a test format, we have shown how it is possible to separate those actors who merely represent the political reality localized in the test from those actors who are subjected to the test apparatus. It endows the former with a kind of moral plasticity, which enables them to cope with the 
tension between the uncertainty of 'the world' and rules that help construct a particular 'reality'; they can thus easily deflect the critique. In contradistinction, the latter become 'contact points' for domination by establishing truths about themselves, which creates critical traction for ostensibly neutral processes; they come to embody their domination.

In attending to the local and embodied processes of domination, our findings also bridge Boltanski's theory of domination with Foucault's ideas of subjectivation by showing how the production of truth becomes a technology of domination. By endowing employees with both the capacity to critique the organization and the responsibility for their work roles, any illness, failure or mishap becomes a test of their worth. Responses require self-disciplinary improvements (Foucault, 1988) or confessions of personal or private impairments (Foucault, 2014); both of which institutionalize a particular logic. The critique of the social system itself would be an affirmation that you cannot handle the work or are not willing to take care of yourself, and are not making the most of the flexibility and freedom you are given. This is of course the essence of neo-liberal logic: 'any failure confronted with the established tests can be assimilated to a shortcoming in the one who, of her own free will, did not want to seize "the opportunities offered her" or who proved incapable of so doing' (Boltanski, 2011, p. 128). This logically penalises already disadvantaged groups in society and feeds into discriminatory discourses.

\section{Conclusion}

The policy reforms investigated painted a rather bleak picture of consensus-driven domination in contemporary organizations. The responsibilization of ill employees worked by positioning employees in command of both their current and previous choices, and empowering them to rectify the consequences of past choices by restoring their 'work capacity'. However, the ill employees were rarely economically or psychologically able to exercise this freedom. 
Paradoxically, the neoliberal discourse of freedom (reaching far into their private lives) constrained employee autonomy.

Our analysis engaged the idea of domination as the product of local processes fraught with tensions and disagreements. We conceived of organizational actors as possessing and implementing their own critiques when engaged in the construction of their working lives. Whilst these actors might not be able to articulate the characteristics and effects of deep and enduring asymmetries within the social world, they frequently demonstrate lucidity concerning the injustices they suffer in quotidian organizational life. This has practical implications for critical sociological scholarship. Rather than 'unmasking' domination as if revealing some deeper truth inaccessible to organizational actors, perhaps the role of the critical scholar is to simply make visible and support contestations that are always-already happening. There will always be tensions between the reality and the world that offer alternative interpretations. Scholars can contribute by, in Boltanski's terms, 'making reality more fragile' (Boltanski et al., 2014, p. 581) in order to illuminate the immanent contradictions built into social reality, which itself is much more fragile than the reified picture presented by institutions and their spokespersons (De Cock \& Nyberg, 2016).

The critique of the unfairness of the new policy, supported by the lived experiences of individuals on sick leave, eventually challenged the social order. In Sweden, mass media began to report on individual cases where the NSIA assessed people to have work capacity despite medical evaluations clearly suggesting incapacity to work. The Minister for Social Security, Christina Husmark Pehrsson, could not distinguish herself from the institution and became the face of the new policies. She resigned from the government in 2010 when, following the extensive critique of the sickness absence policy, the government and the opposition parties agreed that it had to change. Since then there has been continuous critique of the policies from unions and medical associations ensuring a lively debate about the Swedish sick leave policies 
in the mass media. The worlds of the different actors who are bodily subjected to the policies challenge the instituting processes and this experienced 'outside' contaminates the social construction of reality, thus keeping the 'what is' open for contestation. While no major changes to sick leave policy have been made to date (mid-2018), the recognized unfairness of the policy might signal that in Sweden (and many other countries) neoliberalism is losing legitimacy. When particular lived experiences critiquing the instituted reality gain recognition as universally unfair, it creates the possibility for collective action to reconfigure what is seen as sensible or just. 


\begin{tabular}{|c|c|c|c|}
\hline Cases & $\begin{array}{l}\text { Status meeting } \\
\text { attendees }\end{array}$ & Interviewees & Outcomes \\
\hline $\begin{array}{l}\text { Case: Elisabet, } \\
\text { medical } \\
\text { secretary }\end{array}$ & $\begin{array}{l}\text { Employee, } \\
\text { supervisor, NSIA } \\
\text { coordinator }\end{array}$ & $\begin{array}{l}\text { Employee, supervisor, } \\
\text { NSIA coordinator }\end{array}$ & $\begin{array}{l}\text { All actors confirm that Elisabet's 'burn out' is } \\
\text { partly due to the organizational workload. The } \\
\text { suggested solution is for Elisabet to consider } \\
\text { other career options. }\end{array}$ \\
\hline $\begin{array}{l}\text { Case: Birgitta, } \\
\text { psychiatrist }\end{array}$ & $\begin{array}{l}\text { Employee, } \\
\text { supervisor, NSIA } \\
\text { coordinator }\end{array}$ & $\begin{array}{l}\text { Employee, supervisor, } \\
\text { NSIA coordinator }\end{array}$ & $\begin{array}{l}\text { Birgitta and the coordinator confirm that the } \\
\text { cardiac dysrhythmia is because of her workload } \\
\text { at the hospital. The suggested solution is for } \\
\text { Birgitta to retire. }\end{array}$ \\
\hline $\begin{array}{l}\text { Case: Marie, } \\
\text { medical orderly }\end{array}$ & $\begin{array}{l}\text { Employee, } \\
\text { supervisor, NSIA } \\
\text { coordinator }\end{array}$ & $\begin{array}{l}\text { Employee, supervisor, } \\
\text { NSIA coordinator }\end{array}$ & $\begin{array}{l}\text { All actors confirm that Marie's carpal tunnel } \\
\text { syndrome is due to her job as a medical orderly. } \\
\text { The suggested solution is for Marie to work } \\
\text { fewer hours or retire from the hospital. }\end{array}$ \\
\hline $\begin{array}{l}\text { Case: Ingrid, } \\
\text { cleaner }\end{array}$ & $\begin{array}{l}\text { Employee, } \\
\text { supervisor, union } \\
\text { representative } \\
\text { (Ingrid's), NSIA } \\
\text { coordinator }\end{array}$ & $\begin{array}{l}\text { Employee, supervisor, } \\
\text { union representative, } \\
\text { NSIA coordinator }\end{array}$ & $\begin{array}{l}\text { All actors confirm that Ingrid's carpal tunnel } \\
\text { syndrome is due to her heavy cleaning duties at } \\
\text { the hospital. The solution is for Ingrid to have } \\
\text { an operation. }\end{array}$ \\
\hline $\begin{array}{l}\text { Case: Sofia, } \\
\text { medical doctor }\end{array}$ & $\begin{array}{l}\text { Employee, } \\
\text { supervisor, HR } \\
\text { specialist, NSIA } \\
\text { coordinator }\end{array}$ & $\begin{array}{l}\text { Employee, supervisor, } \\
\text { HR specialist, NSIA } \\
\text { coordinator }\end{array}$ & $\begin{array}{l}\text { Sofia's back injury is undisputedly due to her } \\
\text { slipping on a wet floor and falling on her back } \\
\text { during work. The individual solutions are } \\
\text { framed as either rehab or finding another job. }\end{array}$ \\
\hline $\begin{array}{l}\text { Case: Kerstin, } \\
\text { medical orderly }\end{array}$ & $\begin{array}{l}\text { Employee, } \\
\text { supervisor, NSIA } \\
\text { coordinator }\end{array}$ & $\begin{array}{l}\text { Employee, supervisor, } \\
\text { NSIA coordinator }\end{array}$ & $\begin{array}{l}\text { Kerstin and her supervisor confirm that her } \\
\text { back injury is partly work related and due to } \\
\text { heavy lifting as a medical orderly. The } \\
\text { suggested solution is mainly for Kerstin to sort } \\
\text { herself out. }\end{array}$ \\
\hline $\begin{array}{l}\text { Case: } \\
\text { Marianne, } \\
\text { psychotherapist }\end{array}$ & $\begin{array}{l}\text { Employee, } \\
\text { supervisor, NSIA } \\
\text { coordinator }\end{array}$ & $\begin{array}{l}\text { Employee, supervisor, } \\
\text { NSIA coordinator }\end{array}$ & $\begin{array}{l}\text { Marianne is on sick leave due to hypertension, } \\
\text { which all actors agree is partly caused by } \\
\text { workload and stress in the hospital. The } \\
\text { solution is for Marianne to better structure her } \\
\text { work. }\end{array}$ \\
\hline $\begin{array}{l}\text { Case: Helena, } \\
\text { nurse }\end{array}$ & $\begin{array}{l}\text { Employee, doctor, } \\
\text { NSIA coordinator }\end{array}$ & $\begin{array}{l}\text { Employee, doctor, } \\
\text { NSIA coordinator }\end{array}$ & $\begin{array}{l}\text { All the actors agree that Helena's 'burnout' is } \\
\text { due to work overload. The individual solution } \\
\text { to the organizational problem is changing her } \\
\text { profession. }\end{array}$ \\
\hline $\begin{array}{l}\text { Case: Inger, } \\
\text { nurse }\end{array}$ & $\begin{array}{l}\text { Employee, } \\
\text { supervisor, doctor, } \\
\text { NSIA coordinator }\end{array}$ & $\begin{array}{l}\text { Employee, supervisor, } \\
\text { doctor, NSIA } \\
\text { coordinator }\end{array}$ & $\begin{array}{l}\text { All the actors agree that Inger's 'burnout' is } \\
\text { due to organizational stress and a heavy } \\
\text { workload. The suggested solution is for Inger } \\
\text { to better manage her work pace and workload. }\end{array}$ \\
\hline $\begin{array}{l}\text { Case: Maria, } \\
\text { nurse }\end{array}$ & $\begin{array}{l}\text { Employee, HR } \\
\text { manager, HR } \\
\text { specialist, } \\
\text { supervisor, NSIA } \\
\text { coordinator, support } \\
\text { person (for Maria) }\end{array}$ & $\begin{array}{l}\text { Employee, HR } \\
\text { specialist, psychiatrist, } \\
\text { NSIA coordinator }\end{array}$ & $\begin{array}{l}\text { All actors confirm that Maria's 'burn out' is at } \\
\text { least partly work related. The suggested } \\
\text { solution is for Maria to find a new profession } \\
\text { in another organization. }\end{array}$ \\
\hline Gender: & Female 30, Male 5 & Female 29, Male 5 & \\
\hline Total: & Observations: 10 & nterviews: 34 & \\
\hline
\end{tabular}

Table 1. Summary of the 10 cases 


\section{References}

Björnberg, U. (2012). Social policy reforms in Sweden: New perspectives on rights and obligations. In: B. Larsson, M. Letell, \& H. Thörn (Eds.), Transformation of the Swedish welfare state. From social engineering to governance (pp. 71-85). Basingstoke: Palgrave Macmillan.

Boltanski, L. (2008). Domination revisited. Graduate Faculty Philosophy Journal, 29(1), 2770.

Boltanski, L. (2011). On critique: a sociology of emancipation. Cambridge: Polity.

Boltanski, L. (2013). A journey through French style critique. In P. du Gay, \& G. Morgan (Eds.), New spirits of capitalism: crises, justifications, and dynamics (pp. 43.59). Oxford: Oxford University Press.

Boltanski, L. (2014). Mysteries and conspiracies: detective stories, spy novels and the making of modern societies. Cambridge: Polity.

Boltanski, L. \& Chiapello, E. (2005). The new spirit of capitalism. London: Verso.

Boltanski, L. Honneth, A., \& Celikates, R. (2014). Sociology of critique or critical theory? Luc Boltanski and Axel Honneth in conversation with Robin Celikates. In: S. Susen \& B. S. Turner (Eds.), The spirit of Luc Boltanski: essays on the pragmatic sociology of critique (pp. 561-589). London: Anthem Press.

Boltanski, L. \& Thévenot, L. (2006). On justification: Economies of worth. Princeton: Princeton University Press.

Bourdieu, P. (2001). Masculine domination. Standford: Stanford University Press.

Burawoy, M. (1979). Manufacturing consent: Changes in the labor process under monopoly capitalism. Chicago: University of Chicago Press.

Dean, M. (2010). Governmentality: Power and rule in modern society. London: Sage. 
De Cock, C. \& Nyberg, D. (2016). The possibility of critique under a financialized capitalism: The case of private equity in the United Kingdom. Organization, 23(4), 465-484.

Fowler, B. (2014). Figures of descent from classical sociological theory: Luc Boltanski. In S. Susen, \& B. S. Turner (Eds.), The spirit of Luc Boltanski: essays on the pragmatic sociology of critique (pp. 67-88). London: Anthem Press.

Foucault, M. (1970). The order of things: An archaeology of the human sciences. London: Tavistock.

Foucault, M. (1988). Technologies of the self. In: Hutton PH, Gutman H, Martin LH (eds) Technologies of the Self: A seminar with Michel Foucault. Amherst, MA: University of Massachusetts Press, 16-49.

Foucault, M. (2014). On the government of the living. Basingstoke: Palgrave Macmillan.

Larsson, B., Letell, M., \& Thörn, H. (Eds.) (2012) Transformations of the Swedish welfare state: Social engineering, governance and governmentality. Basingstoke: Palgrave Macmillan.

Lusinyan, L. \& Bonato, L. (2007). Work absence in Europe. IMF Staff Papers, 54. Washington, DC: International Monetary Fund.

Martin, G. P., \& Waring, J. (2018). Realising governmentality: pastoral power, governmental discourse and the (re) constitution of subjectivities.

https://doi.org/10.1177/0038026118755616

Munro, R. (2017). Creativity, Organisation and Entrepreneurship: Power and Play in the Ecological Press of Money. Organization Studies, 39(2-3), 209-227.

NSIA (2016) Reconciliation meeting. Available at: https://www.forsakringskassan.se/arbetsgivare/tillbaka_till_arbete__rehabilitering/avstamningsmote/ (accessed 14 May 2016).

NSIA (2015) Sick leave 60 days or more. Available at: 
https://www.forsakringskassan.se/wps/wcm/connect/d7d4b78e-39fa-4c2f-bed9ade979b5ff23/socialforsakringsrapport_2015_1.pdf?MOD=AJPERES (accessed 26 July 2018).

Miller, P. \& Rose, N. (2008). Governing the present. Cambridge: Polity.

Stones, R. (2014). Strenghts and simitations of Luc Boltanski's On Critique. In S. Susen \& B. S. Turner (Eds.), The spirit of Luc Boltanski: Essays on the pragmatic sociology of critique (pp. 211-233). London: Anthem Press.

Susen, S. (2014). Luc Boltanski and his critics: an afterword. In S. Susen \& B. S. Turner (Eds.), The spirit of Luc Boltanski: Essays on the pragmatic sociology of critique (pp. 613-801). London: Anthem Press.

Svärdman, H. (2006). Behöver socialförsäkringarna en extreme makeover? (Are the social insurances in need of an extreme makeover?) Stockholm: Premiss.

Van Gestel, N., Nyberg, D. and Vossen, E. (2015). Institutional logics and micro-processes in organizations: A multi-actor perspective on sickness absence management in three Dutch hospitals. In S. Boch Waldorff, A. Reff Pedersen, L. Fitzgerald and E. Ferlie (Eds.) Managing Change - From Health Policy to Practice (55-70). Hampshire: Palgrave Macmillan.

Waring, J., \& Latif, A. (2017). Of shepherds, sheep and sheepdogs? Governing the adherent self through complementary and competing 'pastorates'. Sociology. https://doi.org/10.1177/0038038517690680

Wodak, R. (2013). Analyzing meetings in political and business contexts: Different genres similar strategies? In: C. Cap \& U. Okulska (Eds.), Analyzing genres in political communication. Theory and Practice (pp. 187-221). Amsterdam: John Benjamins. 